bidrag til fagdidaktikken. Bergen: Fag-

bokforlaget.

_ 2015b: Kielitiedon opetusmenetelmien uudet suunnat. Toiminnallinen kielioppi ja kielentäminen. - Teppo Jakonen, Juha Jalkanen, Terhi Paakkinen ja Minna Suni (toim.), Kielen oppimisen virtauksia.

Flows in language learning s. 187-207.

AFinLAn vuosikirja 2015. Suomen soveltavan kielitieteen yhdistyksen julkaisuja n:o 73. Jyväskylä: Suomen soveltavan kielitieteen yhdistys. http://ojs.tsv.fi/ index.php/afinlavk/artivle/view/49401.

RÄttrÿ, KAIsU - VAittinen, Pirjo 2015:

Kahdeksasluokkalaiset käyttämässä kieliopin käsitteitä. - Merja Kauppinen, Matti Rautiainen ja Mirja Tarnanen (toim.),
Elävä ainepedagogiikka. Ainedidaktiikan symposium Jyväskylässä 13.-14.2.2014 s. 192-208.. Ainedidaktisia tutkimuksia 9. Jyväskylä: Jyväskylän yliopisto.

Tainio, LiIsa - Routarinne, SARA 2012: Kieliopin ymmärtäminen ja kieliopillinen ajattelu. Luokanopettajaopiskelijat lausetta hahmottamassa. - Päivi Atjonen (toim.), Oppiminen ajassa - kasvatus tulevaisuuteen s. 249-265. Kasvatusalan tutkimuksia 61. Jyväskylä: Suomen Kasvatustieteellinen Seura.

Vygotsky, Lev Semjonovitš 1982. Ajattelu ja kieli. Suomentaneet Klaus Helkama ja Anja Koski-Jännes. Espoo: Weilin \& Göös.

\title{
Viittomakielisten vanhempien kuulevien lasten kaksikielisyyden kehitys
}

\section{Laura Kanto: Two languages, two mo- dalities. A special type of early bilingual language acquisition in hearing children of Deaf parents. Acta Universitatis Ouluensis B 141. Oulu: Oulun yliopisto 2016. Johdan- to $126 \mathrm{~s}$. ja kolme artikkelia. ISBN 978-952-62-1177-0 (PDF).}

Laura Kannon logopedian alan väitöskirja käsittelee tieteellisesti ja yhteiskunnallisesti ajankohtaista tutkimusaihetta, kaksikielisyyttä, ja erityisesti kaksikielisyyden varhaista kehitystä ensimmäisinä elinvuosina. Kannon tutkimuskohteena on erityinen kaksikielisyyden laji: hän tutkii suomalaisen viittomakielen ja puhutun suomen kielen kehitystä lapsilla, jotka ovat kuulevia mutta joilla ainakin toinen vanhemmista on viittomakielinen kuuro. Kyseessä on siten bimodaalinen, kaksikanavainen, kaksi- kielisyys, jossa omaksuttavat kielet hyödyntävät kahta eri aistia, näköä ja kuuloa. Kaksikanavaista kaksikielisyyttä on kansainvälisesti tutkittu varsin vähän, ja silloinkin lähinnä muutaman lapsen tapaustutkimuksina (esimerkiksi Petitto, Katerelos, Levy, Gauna, Tétreault \& Ferraro 2001; Lillo-Martin, de Quadros, Chen Pichler \& Fieldsteel 2014). Lisäksi varhaisemmat laajemmilla aineistoilla tehdyt tutkimukset ovat tarkastelleet vain puhutun kielen kehitystä ja erityisesti sen puutteita huomioimatta viittomakieltä (esim. Schiff \& Ventry 1976). Kymmenen lapsen kaksikielisen kielenkehityksen seurantatutkimuksena Kannon tutkimus on laajempi kuin aiemmat kansainväliset tutkimukset. Suomessa tutkimus on ilmeisesti ensimmäinen, joka käsittelee kuurojen vanhempien kuulevien lasten molempien kielten kehitystä. Jo täs- 
täkin syystä käsillä on kiinnostava ja tutustumisen arvoinen teos.

Väitöskirja koostuu johdanto-osasta sekä kolmesta artikkelista, jotka Kanto on tehnyt yhdessä kahden ohjaajansa kanssa. Ensimmäinen artikkeli (Kanto, Huttunen \& Laakso 2013) käsittelee kielellisen ympäristön ja kaksikielisen kehityksen suhdetta, ja se on julkaistu Journal of Deaf Studies and Deaf Education -lehdessä. Toinen artikkeli tarkastelee kaksikanavaista kielenkehitystä ja lasten puheen ja eleiden eriyttämistä heidän käyttäessään kieltä videoiduissa leikkitilanteissa (Kanto, Laakso \& Huttunen 2015). Kolmannessa artikkelissa tutkitaan lasten koodinvaihtoja viittomakielen ja puhutun suomen välillä (Kanto, Laakso \& Huttunen painossa). Kaksi jälkimmäistä artikkelia on julkaistu Bilingualism: Language and Cognition -lehdessä.

\section{Tutkimuksen lähtökohdat}

Tutkimus toteutettiin pitkittäisseurantana puolen vuoden välein lasten ollessa 1-3-vuotiaita. Seuranta-aineiston käyttö on työn erityinen ansio ja havainnollistaa hyvin lasten kielellisiä kehityspolkuja. Tutkittavina oli kahdeksan lasta koko kahden vuoden seurannan ajan ja kaksi lasta lyhyemmän ajan. Puolet lapsista oli sellaisia, joiden vanhemmista molemmat olivat kuuroja, ja puolet sellaisia, joiden vanhemmista toinen oli kuuro ja toinen kuuleva. Kaikki lapset omaksuivat samanaikaisesti suomalaista viittomakieltä ja puhuttua suomea. Koska toinen kielistä on vähemmistökieli ja toinen ympäröivän yhteiskunnan valtakieli, tutkija seurasi myös sitä, kummasta kielestä kehittyy vahvempi ja mitkä tekijät siihen vaikuttavat.

Menetelminä tutkimuksessa käytettiin vanhempien haastattelua, vanhempien täyttämiä varhaisen kommunikaation kehityksen seurantalomakkeita (12 ja 24 kuukauden i’issä), Reynellin kielellisen kehityksen testiä (3-vuotiaana) sekä kielellistä analyysia aineistosta, joka kerättiin lasten kotona videoiduista leikkitilanteista. Seurantalomakkeena käytettiin MCDIlomakkeita (MacArthur Communicative Development Inventory; ks. Lyytinen 1999), joihin vanhemmat kirjasivat havaintojaan lapsensa kielen ymmärtämisestä ja tuottamisesta kummallakin kielellä. Tutkija oli muokannut MCDI-testin myös suomalaisen viittomakielen seurantaan sopivaksi versioksi, joten molempia kieliä voitiin tältä osin arvioida samalla mittarilla, mikä lisää tutkimuksen luotettavuutta. Reynellin kielellisen kehityksen testillä (ks. Kortesmaa, Heimonen, Merikoski, Warma \& Varpela 2001) tutkittiin vain puhuttua suomea, sillä suomalaiselle viittomakielelle vastaavia arviointimenetelmiä ei vielä Suomessa ole eikä vertailua siten voitu tehdä.

Normatiivisten testien käyttö on tyypillistä logopedian alan tutkimuksissa, mutta Kannon tutkimuksessa haettiin tietoa myös laajemmin haastattelemalla vanhempia sekä tutkimalla lasten kielenkäyttöä. Haastattelemalla vanhempia pyrittiin kartoittamaan erilaisia ympäristöja taustatekijöitä, kuten viittomakielelle ja suomen kielelle altistumisen määrää, mikä voi vaikuttaa kielten kehitykseen. Lasten kotiympäristössä videoiduissa leikkitilanteissa (45 min.) lapsi leikki ensin kuuron vanhemman kanssa, sitten kuuron vanhemman ja kuulevan aikuisen kanssa ja lopuksi kuulevan aikuisen kanssa. Näin pyrittiin selvittämään vuorovaikutuskumppanin vaikutusta kielenkäyttöön ja erityisesti sitä, pystyykö lapsi vaihtamaan kieltä kumppanin käyttämän kielen mukaisesti. Lasten kielellisestä ilmaisusta analysoitiin muun muassa kommunikaatiotapaa (ele, viittoma, ääntely, sana), sanastoa ja ilmausten keskipituutta.

\section{Uutta tietoa kaksikanavaisesta kaksikielisyydestä}

Kannon väitöskirjasta nousee esiin kolme merkittävää päähavaintoa. Ensinnäkin väitöskirja tarkastelee monipuolisesti niitä 
tekijöitä, jotka voivat vaikuttaa kaksikielisyyden kehitykseen ja tuoda siihen haasteita. Kielten kehityksessä ja kieliympäristöissä oli suuria yksilöllisiä eroja lasten välillä, ja vähemmistökielenä viittomakieli jäi herkästi jälkeen puhutun suomen kehityksestä. Haastattelemalla saaduista tiedoista ei kuitenkaan saatu täysin selviä tilastollisesti merkitseviä yhteyksiä esimerkiksi eri kielille altistumisen määrän ja kielten kehityksen ja vahvuuden välille. Toiseksi tutkimus vahvistaa bimodaalisen kaksikielisyyden osalta samoja havaintoja, joita on tehty puhutun kaksikielisyyden tutkimuksessa - esimerkiksi sitä, että kaksikielisillä kahden kielen yhteenlaskettu tuottava sanasto vastaa yksikielisten sanaston laajuutta. Havainto päti ryhmätasolla, mutta yksilöiden välinen vaihtelu oli kuitenkin hyvin suurta. Kolmanneksi tutkimuksessa löydettiin jo yksivuotiaiden kielenkäytössä kielten eriytymistä vuorovaikutuskumppanin mukaan, mitä ei aiemmassa puhutun kielen tutkimuksessa ole voitu osoittaa näin varhaisella iällä. Lapset käyttivät eleitä ja viittomia viittomakielisen kuuron vanhemman kanssa ja ääntelyä ja sanoja suomea puhuvan kuulevan aikuisen kanssa. Kahden erilaisen viestintäkanavan käytön vuoksi kielten eriytynyt käyttö oli selvemmin havaittavissa jo yksivuotiaana. Kanto ja kumppanit pitävät eriytymistä merkkinä kahden kielijärjestelmän yhtäaikaisesta omaksumisesta jo kielenkehityksen alkuvaiheista alkaen, mikä on tärkeä havainto kaksikielisyysteorioiden kannalta.

Kannon väitöstutkimus tuo siis merkittävää uutta tietoa kielijärjestelmien varhaisesta rinnakkaisesta kehityksestä ja vahvistaa kaksikielisyysteorioissa esiintyvää niin sanottua kahden kielijärjestelmän hypoteesia (ks. Genesee 1989). Tutkimuksen pienehkön aineiston vuoksi tulokset ovat vielä suuntaa antavia, mutta herättävät mielenkiintoisia jatkotutkimusaiheita, joita voisi kartoittaa laajemmalla aineistolla. Suurempi tutkittavien määrä ja etnografisempi lasten seuranta ja videointi arkielämän ti- lanteissa voisivat tuoda lisätietoa lasten kielenkäytön vaihtelusta ja kehityksestä.

\section{Kokoavaa arviointia}

Laura Kannon väitöskirja tuo uutta tietoa suomalaisen viittomakielen ja puhutun suomen kielen yhtäaikaisen omaksumisen varhaisvaiheista lapsilla, jotka ovat kuulevia ja joiden vanhemmat ovat kuuroja. Aineiston lasten erilaiset kielenkehityksen polut tuovat esiin sen, että lapset oppivat kielen vuorovaikutuksessa läheisten ihmisten ja ympäristön kanssa ja että vähemmistökielen ja valtakielen suhde voi tällöin olla haastava ja jännitteinen. Vähemmistökielten tutkimuksessa aiemminkin havaittu piirre aineistossa oli se, että lasten puhutun suomen kielen kehitys alkoi seurannan aikana vahvistua, kun taas vähemmistökielenä suomalainen viittomakieli ei kehittynyt yhtä hyvin. Myös kielten sekoittuminen oli yleisempää vähemmistökieltä käytettäessä. Toisaalta erityistä oli se, että lapset saattoivat sulauttaa eri kielten koodeja ja käyttää yhtä aikaa sekä viittomaa että sanaa, mitä kahta puhuttua kieltä käytettäessä ei voi tehdä. Seitsemässä perheessä vanhemmat olivat haastattelujen perusteella kuitenkin jossain määrin huolissaan lapsensa kielenkehityksestä.

Kannon tutkimus haastaa miettimään laajemminkin kuin vain viittomakielen osalta vähemmistökielten asemaa ja niiden tukemisen tärkeyttä, jotta lapsi voi kehittyä tasapainoisesti kaksikieliseksi. Tutkimus tuo esiin myös kaksikielisille sopivien ja erityisesti viittomakieltä kartoittavien kielellisten arviointimenetelmien kehittämisen tärkeyden. Laura Kannon väitöstyöllä on siten merkitystä sekä kaksikielisyyteen liittyvien teorioiden että kaksikieliseen kielenkehitykseen liittyvien käytännön sovellusten kannalta. Kaksikielisiksi kasvavien lasten kielenkehityksen erityispiirteiden tutkiminen on jatkossakin hyvin ajankohtaista. 


\section{Minna LaAKSO \\ etunimi.sukunimi@utu.fi}

\section{Lähteet}

Genesee, Fred 1989. Early bilingual development, one language or two? - Journal of Child Language 16 s. 161-179.

Kanto, Laura - Huttunen, KertTU - LAAKso, MARJA-LEena 2013: Relationship between the linguistic environment and early bilingual language development of hearing children in Deaf-parented families. - Journal of Deaf Studies and Deaf Education $18 \mathrm{~s}$. 242-260.

Kanto, Laura, - Laakso, MarjaLeena - Huttunen, Kerttu 2015: Differentiation in language and gesture use during early bilingual development of hearing children of Deaf parents. Bilingualism. Language and Cognition 18 s. 769-788.

— painossa: Code-mixing by young hearing children of Deaf parents. - Bilingualism. Language and Cognition. DOI: https:// doi.org/10.1017/S1366728916000560.

Kortesmaa, Marketta - Heimonen, Krista - Merikoski, Hannele

- Warma, Maija-Leena - Varpe-
LA, VIRPI 2001: Reynellin kielellisen kehityksen testi. Helsinki: Psykologien Kustannus.

Lillo-Martin, Diane - De Quadros, Ronice M. - Chen Pichler, Deborah - Fieldsteel, Zoe 2014. Language choice in bimodal bilingual development. - Frontiers in Psychology 5 s. $153-167$.

Lyytinen, Paula 1999: Varhaisen kommunikaation ja kielen kehityksen arviointimenetelmä. Jyväskylä: Niilo Mäki Instituutti \& Jyväskylän yliopiston lapsitutkimuskeskus.

Petitto, Laura Ann - Katerelos, Marina - Levy, Bronna - Gauna, Kristine - Tétreault, Karine Ferraro, Vittoria 2001: Bilingual signed and spoken language acquisition from birth. Implications for the mechanisms underlying early bilingual language acquisition. - Journal of Child Language 28 s. 453-496.

Schiff, NaOmi - Ventry, Ira 1976: Communication problems in hearing children of deaf parents. - Journal of Speech and Hearing Disorders $41 \mathrm{~s}$. 848-858.

\section{Miten sanoilla toimitaan - J. L. Austinin klassikko suomeksi}

\section{J. L. Austin: Näin tehdään sanoilla. Harvardissa 1955 pidetyt William James -luennot. Alkuperäisteos How to do things with words 1962. Suomentanut Risto Koskensilta. Tampere: niin \& näin 2016. 186 s. ISBN 978-952-7189-05-4.}

Tieteellisen termistön vakiinnuttaminen Suomen oloihin on työlästä ja usein satun- naista. Harvemmin se on yhden ihmisen työtä, ja ensi yritykset leviävät vaivoin yksittäisestä artikkelista. Kurssikirjat, klassikoiden suomennokset sekä viime aikoina myös Tieteen termipankki ovat olleet keskeisiä termistön vakiinnuttajia. Varsinkin filosofit ovat kadehdittavan perusteellisesti ryhtyneet suomentamaan kaikkein vaativimpiakin ajattelijoita Aristoteleestä 